\title{
接着接合板における接着層厚さが特異応力の強さに与える影響*
}

\author{
張 玉 $^{* 1}$, 野田尚昭 ${ }^{* 2}$, 高石謙太郎 ${ }^{* 3}$, 蘭 欣 ${ }^{* 4}$
}

\section{Effect of Adhesive Thickness on the Interface of Singular Stress at the Adhesive Dissimilar Joint}

\author{
Yu ZHANG, Nao-Aki NODA*2, Ken-Taro TAKAISHI and Xin LAN \\ *2 Department of Mechanical and Control Engineering, Kyushu Institute of Technology, \\ 1-1 Sensui- cho, Tobata-ku, Kitakyushu-shi, Fukuoka, 804-8550 Japan
}

This paper deals with the singular stress field at the adhesive dissimilar joint, and discusses the effect of material combination and adhesive thickness on the intensity of the singular stress when bonded strip is subjected to tension. A useful method to calculate the intensity of singular stress at the adhesive dissimilar joint is presented with focusing on the stresses at the edge calculated by finite element method. The intensities of singular stress are indicated in charts with varying adhesive thickness $t$ under arbitrary material combinations for adhesive and adherents, and it is found that the intensity of singular stress increases with increasing the adhesive thickness $t$ until $t=W$, when $W$ is the width of adhesive. The intensity of singular stresses are also charted under arbitrary material combinations which are presented by Dundurs' parameters $\alpha, \beta$ when $t / W=0.001$ and $t / W=0.1$, and it is found that for a fixed value $\beta$ the intensity of singular stress increases with increasing $\alpha$ when $\alpha$ is small while it decreases with increasing $\alpha$ when $\alpha$ is large.

Key Words : Elasticity, Fracture Mechanics, Finite Element Method, Intensity of Singular Stress, Adhesive

\section{1. 緒言}

工業の多くの分野て接着剂による接合か頻繁に使用されている．弚の応用範囲は広く，自動車産業や造船業や 航空業など樣々な産業て使用されている．また，接着阁による接合は，今日では複合材料を用いた歯の治療にも よく利用されている(1)，(2)，弚のような歯の治療における，複合材料の接着剂による接合の有効性を評価するため， 図 1 のような微小試験片に引張りを与える実験力行われている(3) .この試験はつき合わせ接合強度試験の小型化 版とみなすことができ，弚の試験片の縦断面は図 2 のような長方形断面である .

しかしながら，ある種の材料組合せにおいては，異種材料界面の接合端部て特異応力が発生することがあり， ぞれは構造物の接合部の損傷へとつながる .この損傷を生じる厳しさの評価は特異応力場の強さによって表現さ

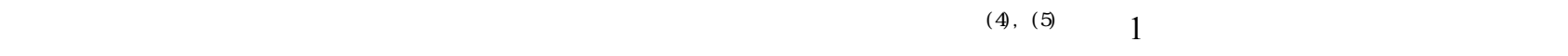
らなる微小接合試験片に引張りを負荷した場合の応力分布に関する研究は少ない . また , 特に, 产のような微小 試験片 (のの接着斉の接合端部での特異応力場の強さに注目し，关の強さを議論した研究は見当たらない.従って， これまでに行われた実験結果より，接着層厚さが大きくなると接合強度は下がることがわかっている(7けれども， 弚の理由ははっきりとは説明されていない .

\footnotetext{
原稿受付 2010 年 11 月12 日 , Journal of Solid Mechanics and Materials Engineering, Vol.4, No.10(2010), pp.1467-1479 (原稿受付 2010 年 4 月 22 日)

${ }^{* 1}$ 正員, 九州工業大学大学院工学研究科 币 8048550 福岡県北九州市戶畑区仙水町 1- 1)

*2 正員, 九州工業大学工学研究院

*3 九州工業大学大学院工学研究科

$*_{4}$ 学生員, 九州工業大学大学院工学研究科

E-mail: noda@mech.kyutech.ac.jp
} 


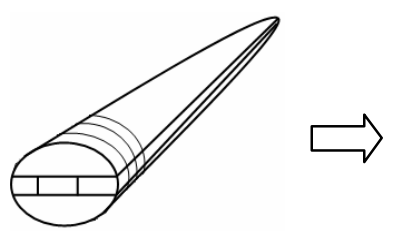

Fig.1 Micro-tensile bond test

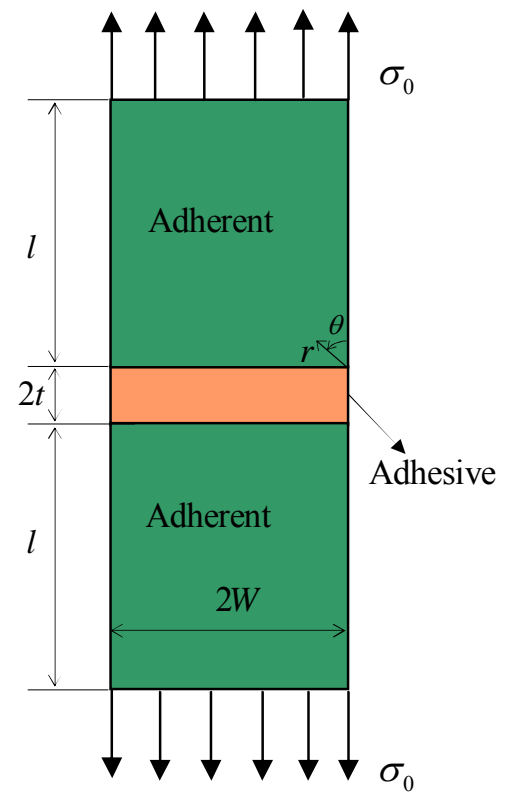

Fig.2 Adhesive joint

\section{2. 解析方法}

図 2 に示すような接着斉により接合された接合板の問題を考える . この界面の応力 $\sigma_{i j}(i j=r r, \theta \theta, r \theta)$ は接合端 部で無限大となる .すなわち $\alpha(\alpha-2 \beta)>0$ のとき $\sigma_{i j} \propto 1 / r^{1-\lambda}$ の特異性を示す .ここで， $\alpha ， \beta$ は Dundurs'の複 合材料パラメーターでありポアソン比 $v$ と横弾性係数 $G$ により表せる.また， $\theta=\pi / 2$ のとき接合界面における 特異応力 $\lambda$ は式 (1) により求められる ${ }^{(8),(9)}$. 表 1 に式 (1) により得られる $\lambda$ の值を示す. 表より $\alpha(\alpha-2 \beta)>0$ のとき $\lambda<1$ となり， $\alpha(\alpha-2 \beta)=0$ のとき $\lambda=1$ となり， $\alpha(\alpha-2 \beta)<0$ のき $\lambda>1$ となることがわかる.

$$
\begin{gathered}
{\left[\sin ^{2}\left(\frac{\pi}{2} \lambda\right)-\lambda^{2}\right]^{2} \beta^{2}+2 \lambda^{2}\left[\sin ^{2}\left(\frac{\pi}{2} \lambda\right)-\lambda^{2}\right] \alpha \beta+\lambda^{2}\left(\lambda^{2}-1\right) \alpha^{2}+\frac{\sin ^{2}(\lambda \pi)}{4}=0} \\
\alpha=\frac{G_{1}\left(\kappa_{2}+1\right)-G_{2}\left(\kappa_{1}+1\right)}{G_{1}\left(\kappa_{2}+1\right)+G_{2}\left(\kappa_{1}+1\right)} \quad \beta=\frac{G_{1}\left(\kappa_{2}-1\right)-G_{2}\left(\kappa_{1}-1\right)}{G_{1}\left(\kappa_{2}+1\right)+G_{2}\left(\kappa_{1}+1\right)} \\
\kappa_{j}=\left\{\begin{array}{ll}
\frac{3-v_{j}}{1+v_{j}}(\text { plane } & \text { stress }) \\
3-4 v_{j} \text { (plane } & \text { strain })
\end{array}, \kappa_{j}=\quad(j=1,2)\right.
\end{gathered}
$$

接着斉による接合端部の特異応力場の強さ $K_{\sigma}$ は，

$$
K_{\sigma}=\lim _{r \rightarrow 0}\left[r^{1-\lambda} \times \sigma_{\theta \mid \theta=\pi / 2}(r)\right]
$$

と表され，これを無次元化特異応力場の強さ $F_{\sigma}$ とし次式により定義する.

$$
F_{\sigma}=\frac{K_{\sigma}}{\sigma_{0}(2 W)^{1-\lambda}}=\frac{\lim _{r \rightarrow 0}\left[r^{1-\lambda} \sigma_{\theta \mid \theta=\pi / 2}(r)\right]}{\sigma_{0}(2 W)^{1-\lambda}}
$$

ここで $\sigma_{0}$ は遠方における $y$ 方向応力である . 
Table 1 Values of singular index $\lambda$

[ Red figures indicate $\lambda<1$, blue figures indicate $\lambda>1$, black figures indicate $\lambda=1$ ]

\begin{tabular}{|c|c|c|c|c|c|c|c|c|c|c|c|}
\hline \hline$\alpha$ & $\beta=-0.45$ & $\beta=-0.4$ & $\beta=-0.3$ & $\beta=-0.2$ & $\beta=-0.1$ & $\beta=0$ & $\beta=0.1$ & $\beta=0.2$ & $\beta=0.3$ & $\beta=0.4$ & $\beta=0.45$ \\
\hline-1.00 & 0.87624 & 0.8073 & 0.7205 & 0.6646 & 0.6247 & 0.5946 & & & & & \\
\hline-0.95 & 0.9349 & 0.8536 & 0.7576 & 0.6975 & 0.6550 & 0.6232 & & & & & \\
\hline-0.90 & 1.00000 & 0.9008 & 0.7941 & 0.7295 & 0.6845 & 0.6511 & & & & & \\
\hline-0.80 & & 1.0000 & 0.8655 & 0.7916 & 0.7415 & 0.7048 & & & & & \\
\hline-0.70 & & 1.1174 & 0.9348 & 0.8510 & 0.7961 & 0.7564 & & & & & \\
\hline-0.60 & & & 1.0000 & 0.9071 & 0.8480 & 0.8060 & 0.7746 & & & & \\
\hline-0.50 & & & 1.0558 & 0.9580 & 0.8966 & 0.8532 & 0.8210 & & & & \\
\hline-0.40 & & & 1.0913 & 1.0000 & 0.9403 & 0.8974 & 0.8655 & & & & \\
\hline-0.30 & & & 1.0964 & 1.0276 & 0.9761 & 0.9371 & 0.9075 & & & & \\
\hline-0.20 & & & 1.0756 & 1.0360 & 1.0000 & 0.9699 & 0.9457 & 0.9269 & & & \\
\hline-0.10 & & & & 1.0251 & 1.0083 & 0.9921 & 0.9777 & 0.9659 & & & \\
\hline 0.00 & & & & 1.0000 & 1.0000 & 1.0000 & 1.0000 & 1.0000 & & & \\
\hline 0.10 & & & & 0.9659 & 0.9777 & 0.9921 & 1.0083 & 1.0251 & & & \\
\hline 0.20 & & & & 0.9269 & 0.9457 & 0.9699 & 1.0000 & 1.0360 & 1.0756 & & \\
\hline 0.30 & & & & & 0.9075 & 0.9371 & 0.9761 & 1.0276 & 1.0964 & & \\
\hline 0.40 & & & & & 0.8655 & 0.8974 & 0.9403 & 1.0000 & 1.0913 & & \\
\hline 0.50 & & & & & 0.8210 & 0.8532 & 0.8966 & 0.9580 & 1.0558 & & \\
\hline 0.60 & & & & & 0.7746 & 0.8060 & 0.8480 & 0.9071 & 1.0000 & & \\
\hline 0.70 & & & & & & 0.7564 & 0.7961 & 0.8510 & 0.9348 & 1.1174 & \\
\hline 0.80 & & & & & & 0.7048 & 0.7415 & 0.7916 & 0.8655 & 1.0000 & \\
\hline 0.90 & & & & & & 0.6511 & 0.6845 & 0.7295 & 0.7941 & 0.9008 & 1.0000 \\
\hline 0.95 & & & & & & 0.6232 & 0.6550 & 0.6975 & 0.7576 & 0.8536 & 0.9349 \\
\hline 1.00 & & & & & & 0.5946 & 0.6247 & 0.6646 & 0.7205 & 0.8073 & 0.8762 \\
\hline
\end{tabular}

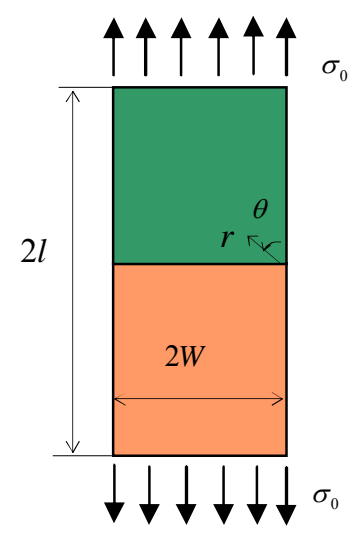

Fig.3 Bonded strip

本論文では有限要素法を用いて接合界面の応力を求める . 対称性を考慮して図 2 の $1 / 4$ モデルを用いて解析を 行う. 被接着斉のヤング率とポアソン比を $E_{1}, v_{1}$ とし , 接着斉のヤング率とポアソン比を $E_{2}, v_{2}$ とする . モデル の幅を $2 \mathrm{~W}=2000 \mathrm{~mm}$ とし,$l \geq 2 W$ の場合は界面において同じ応力を示すことか確認されたので,$l=2 \mathrm{~W}$ とする . この条件下て接着層厚さ $t / W$ を $0.001,0.01,0.1,0.5,1,2,4$ と変化させて解析を行う.

まず, 有限要素法を用いた特異応力場の強さの計算方法を提案する.ここでは特異応力場の強さの比 $K_{\sigma}^{1} / K_{\sigma}^{2} に$ 注目する.ここで，比 $K_{\sigma}^{1} / K_{\sigma}^{2}$ に注目する理由は，後述するように，この比を求める方が $K_{\sigma}$ を直接求めるより解 析か容易となるからである.また , 添え字の 1,2 は異なる $t / W$ の結果であることを意味している.式 (5) に示 すように無次元化した特異応力場の強さ $F_{\sigma}$ は, 距離 $r$, 特異指数 $\lambda$, 応力 $\sigma_{0}$, 幅 $W, \lim _{r \rightarrow o} \sigma_{\theta \mid \theta=\pi / 2}$ の極限に関連 する. 異なる接着層厚さ $t_{1}, t_{2}$ の問題を, 光れ問題 1 , 問題 2 とし, 両者に無限遠で同じ大きさの応力 $\sigma_{y}=\sigma_{0}$ を負荷し同じ材料組合せで考察する．従って，問題 1 と問題 $2 て ゙ ， \lambda_{1}=\lambda_{2}$ である.よって，式 (6) に示すよう に特異応力場の強さの比 $K_{\sigma}^{1} / K_{\sigma}^{2}$ は， 応力の比 $\lim _{r \rightarrow o}\left(\sigma_{\theta \mid \theta=\pi / 2}^{1} / \sigma_{\theta \mid \theta=\pi / 2}^{2}\right)$ にっってのみ決まる． 


$$
\frac{K_{\sigma}^{1}}{K_{\sigma}^{2}}=\frac{\sigma_{0}^{1}(2 W)^{1-\lambda_{1}} F_{\sigma}^{1}}{\sigma_{0}^{2}(2 W)^{1-\lambda_{1}} F_{\sigma}^{2}}=\frac{F_{\sigma}^{1}}{F_{\sigma}^{2}}=\lim _{r \rightarrow 0} \frac{\left[r^{1-\lambda_{1}} \sigma_{\theta \mid \theta=\pi / 2}^{1}(r)\right]}{\left[r^{1-\lambda_{1}} \sigma_{\theta \mid \theta=\pi / 2}^{2}(r)\right]}=\lim _{r \rightarrow 0} \frac{\sigma_{\theta \mid \theta=\pi / 2}^{1}(r)}{\sigma_{\theta \mid \theta=\pi / 2}^{2}(r)}
$$

本解析では主に特異応力の強さの比を考慮し解析する . 光して, 応力の比から特異応力の強さを得るために, 図 3 の解を基準問題として使用する .

\section{3. 有限要素法により得られる界面の応力分布と光の比}

まず図 4 に $t / W=1$ のときの $\alpha=0.8, \beta=0.1, \alpha=0.9, \beta=0.3, \alpha=0.3, \beta=0, \alpha=0.2, \beta=0.1, \alpha=0.2, \beta=0.2$ の場合の接着剂と被接着斉の間の界面における応力分布を示す . $\alpha(\alpha-2 \beta)>0$ のときは界面での応力は $\alpha, \beta$ の 值によらず無限大になり， $\alpha(\alpha-2 \beta)=0$ のときは一定となり， $\alpha(\alpha-2 \beta)<0$ のときは 0 となることがわかる . 有限要素法では, 通常接着剂と被接着剂の界面の応力は一致しないので, 本解析では接着剂と被接着斉の結果か ら外挿し，弚の平均值を用いることによって界面に沿っての応力分布を求める．

接着層厚さ力特異応力場の強さに与える影響を理解するため, 接着層厚さを変化させた場合の応力分布を考察 する. 図 5 (a) に $\alpha=0.3, \beta=0$ の場合における接着層厚さ $t / W$ を $0.001,0.01,0.1,0.5,1,2,4$ と変化させて 界面の応力分布を示す.また，乥の詳細を図 5 (b) に界面の端部における特異応力分布を拡大して示す . 接着層 厚さか増加すると特異応力を示す領域がかな増加することがわかる . また $t / W=1,2,4$ の場合 , ほとんど同じ 応力分布を示す . 界面端部における応力分布を詳しく理解するため, 接着層厚さを変化させたときの応力の比を 図 5 (c) に示す . 図 5 (c) より応力は急激に増加することがわかる .ただし , 真の応力は $r \rightarrow 0$ て無限大となる が, 有限要素法では特異応力を正確に表すことができない . しかしここで注目すべきことは, 異なる $t / W$ の応力 分布の線が $r / W$ に沿ってほぼ平行となっていることである

図 6 に示すように，W=1000mm の場合，最小メッシュサイズとして $1 / 3^{8}=1 / 6561$ を用いると，接着斉接合端 部付近の応力分布の比 $\sigma_{y}^{d} / \sigma_{y t / W=1}$ は一定となることがわかる . 有限要素法により端部の特異性を正確に示すのは困 難であるけれども, 図 6 のように特異性を示す領域においても $\sigma_{y} / \sigma_{y t / W=1}$ の比については正確に求めることができ る。

より詳しく検討するため, 最小メッシュサイズ $1 / 3^{8}=1 / 6561$ で有限要素法を用いて得られた結果の比と応力分 布を表 2 (a) で比較する.表 2 (a) より応力の比は $r$ に依存せず 4 林一致していることがわかる.表 2 (b) は 最小メッシュサイズ $1 / 3^{4}=1 / 81 \mathrm{~mm}$ での結果である.この場合， $r$ に依存せず 3 椼一致していることがわかる.ま た，表 2 (a)，(b) の比は，互いに3 桁まで一致している . 応力の值はメッシュサイズに大きく依存するので， 有限要素法を用いて特異応力を表現することは容易ではないが, 表 2 より応力の比は正確に求められることがわ かる . 言い換えると，界面の応力の比はメッシュサイズに依存しないことがわかる .

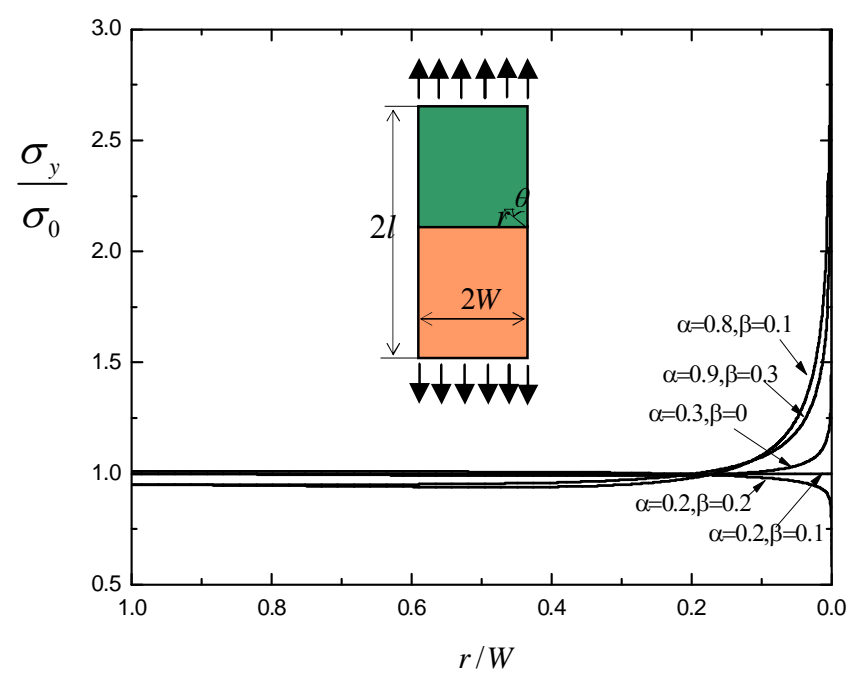

Fig.4 The stress distribution on the interface with different material combination. 
2 章より, $r$ に沿って $K_{\sigma}{ }^{1} / K_{\sigma}{ }^{2}$ の比と $\sigma_{y}{ }^{1} / \sigma_{y}{ }^{2}$ の比は一致し, 表 2 に示す $\sigma_{y}{ }^{1} / \sigma_{y}{ }^{2}$ の值は $r$ に依存しないため 異種材料接合端部における応力のみを考慮する。

以下は基準問題の特異応力の強さ $K_{\sigma}^{2}$, 未知問題の特異応力の強さ $K_{\sigma}^{1}$ として,$K_{\sigma}{ }^{1} / K_{\sigma}{ }^{2}$ の値について議論する.
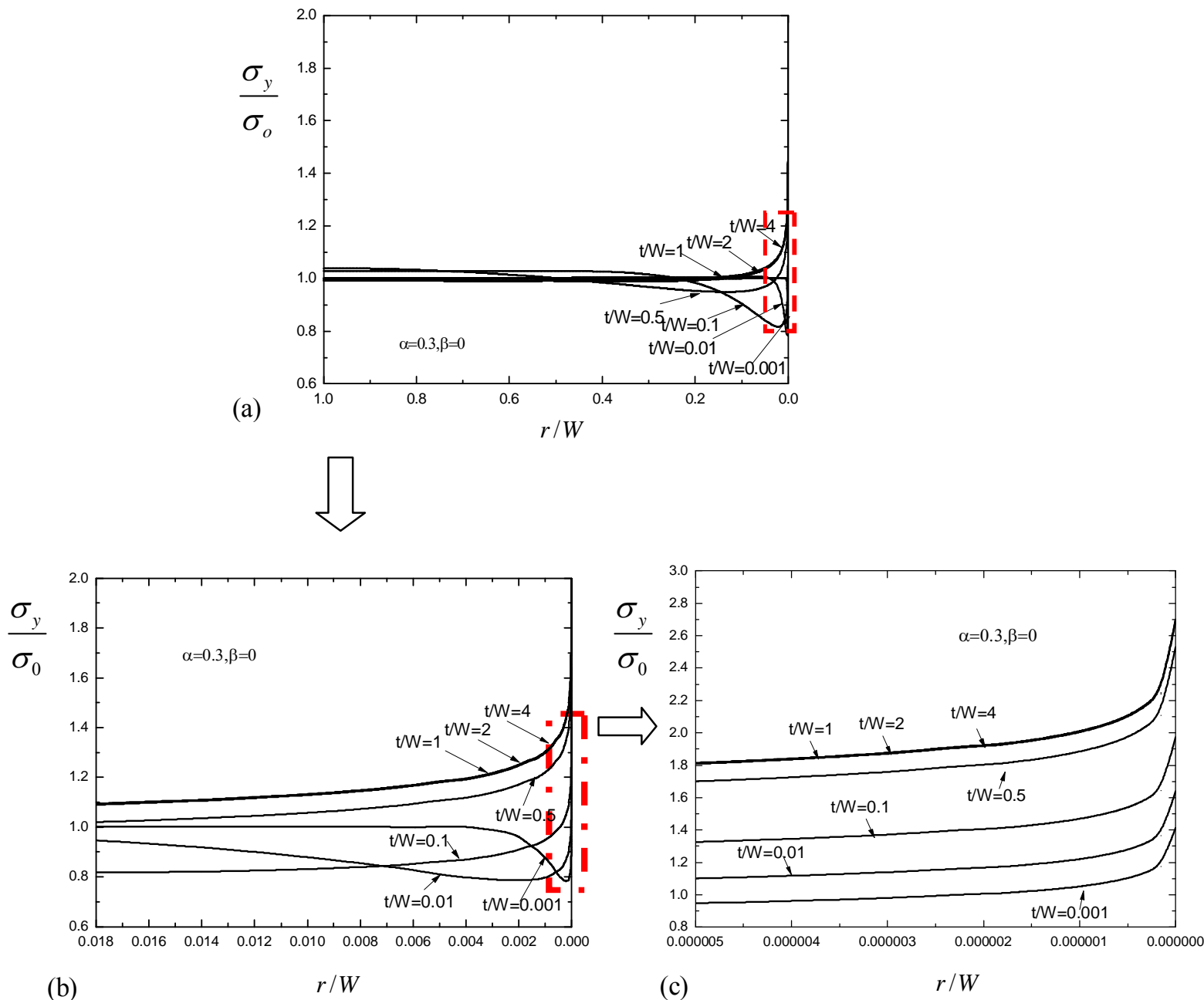

Fig.5 Stress distribution $\sigma_{y}$ on the interface with different adhesive thickness.
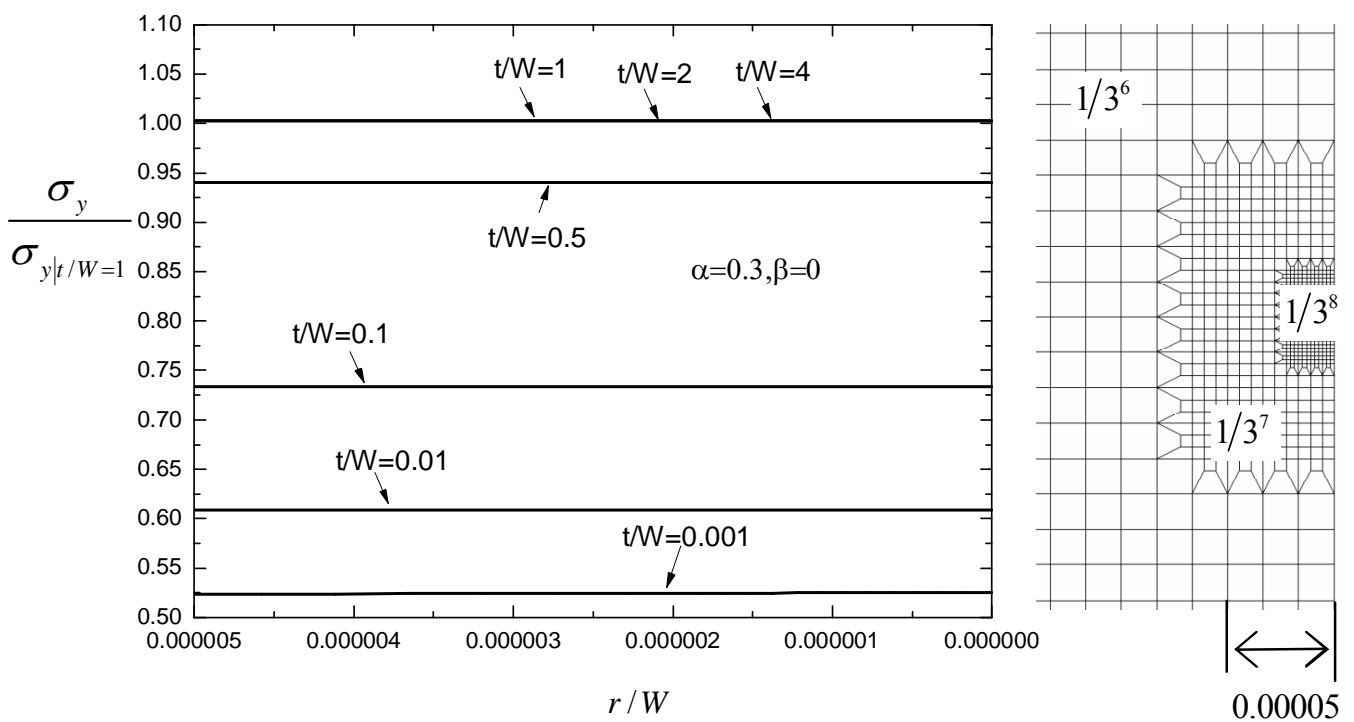

Fig. 6 Ratio of $\sigma_{v}^{1} / \sigma_{v t / W=1}$ near the edge of adhesive joint. 
Table 2 Stress distribution $\sigma_{y}$ along the interface when $\alpha=0.3, \beta=0$. The ratio of stress distributions $\sigma_{y} / \sigma_{y / t / W=1}$ are indicated in parentheses.

(a) $\sigma_{y}$ and $\left(\sigma_{y} / \sigma_{y / t / W=1}\right)$ obtained with the smallest mesh size $1 / 3^{8}=1 / 6561 \mathrm{~mm}$ and $W=1000 \mathrm{~mm}$

\begin{tabular}{|c|c|c|c|c|c|c|c|}
\hline \hline $\begin{array}{c}\text { T } \\
r / W\end{array}$ & 0.001 & 0.01 & 0.1 & 0.5 & 1 & 2 & 4 \\
\hline$\rightarrow 0$ & & & & & & & \\
\hline $1 / 6561000$ & $1.1714(0.525)$ & $1.640(0.609)$ & $1.973(0.733)$ & $2.530(0.940)$ & $2.692(1.000)$ & $2.700(1.003)$ & $2.670(1.003)$ \\
\hline $2 / 6561000$ & $1.138(0.525)$ & $1.365(0.609)$ & $1.644(0.733)$ & $2.108(0.940)$ & $2.242(1.000)$ & $2.249(1.003)$ & $2.249(1.003)$ \\
\hline $3 / 6561000$ & $1.109(0.525)$ & $1.286(0.609)$ & $1.548(0.733)$ & $1.985(0.940)$ & $2.111(1.000)$ & $2.118(1.003)$ & $2.117(1.003)$ \\
\hline $4 / 6561000$ & $1.088(0.525)$ & $1.262(0.609)$ & $1.519(0.733)$ & $1.948(0.940)$ & $2.072(1.000)$ & $2.078(1.003)$ & $2.078(1.003)$ \\
\hline $5 / 6561000$ & $1.071(0.525)$ & $1.243(0.609)$ & $1.497(0.733)$ & $1.919(0.940)$ & $2.041(1.000)$ & $2.047(1.003)$ & $2.047(1.003)$ \\
\hline $6 / 6561000$ & $1.058(0.525)$ & $1.228(0.609)$ & $1.478(0.733)$ & $1.896(0.940)$ & $2.016(1.000)$ & $2.022(1.003)$ & $2.022(1.003)$ \\
\hline $7 / 6561000$ & $1.047(0.525)$ & $1.215(0.609)$ & $1.463(0.733)$ & $1.876(0.940)$ & $1.995(1.000)$ & $2.002(1.003)$ & $2.001(1.003)$ \\
\hline $8 / 6561000$ & $1.038(0.525)$ & $1.205(0.609)$ & $1.450(0.733)$ & $1.859(0.940)$ & $1.978(1.000)$ & $1.984(1.003)$ & $1.984(1.003)$ \\
\hline $9 / 6561000$ & $1.030(0.525)$ & $1.195(0.609)$ & $1.439(0.733)$ & $1.845(0.940)$ & $1.962(1.000)$ & $1.968(1.003)$ & $1.968(1.003)$ \\
\hline
\end{tabular}

(b) $\sigma_{y}$ and $\left(\sigma_{y} / \sigma_{y / t / W=1}\right)$ obtained with the smallest mesh size $1 / 3^{4}=1 / 81 \mathrm{~mm}$ and $W=1000 \mathrm{~mm}$

\begin{tabular}{|c|c|c|c|c|c|c|c|}
\hline \hline \multicolumn{1}{|c|}{$t / W$} & 0.001 & 0.01 & 0.1 & 0.5 & 1 & 2 & \multirow{2}{*}{4} \\
\hline$r / W$ & & & & & & \\
\hline $1 / 81000$ & $0.889(0.522)$ & $1.036(0.609)$ & $1.249(0.733)$ & $1.601(0.940)$ & $1.703(1.000)$ & $1.708(1.003)$ & $1.708(1.003)$ \\
\hline $2 / 81000$ & $0.859(0.522)$ & $1.001(0.608)$ & $1.207(0.733)$ & $1.548(0.940)$ & $1.647(1.000)$ & $1.652(1.003)$ & $1.652(1.003)$ \\
\hline $3 / 81000$ & $0.838(0.522)$ & $0.975(0.608)$ & $1.176(0.733)$ & $1.508(0.940)$ & $1.604(1.000)$ & $1.609(1.003)$ & $1.608(1.003)$ \\
\hline $4 / 81000$ & $0.824(0.523)$ & $0.956(0.608)$ & $1.154(0.733)$ & $1.480(0.940)$ & $1.574(1.000)$ & $1.579(1.003)$ & $1.579(1.003)$ \\
\hline $5 / 81000$ & $0.813(0.525)$ & $0.942(0.607)$ & $1.137(0.733)$ & $1.458(0.940)$ & $1.551(1.000)$ & $1.555(1.003)$ & $1.555(1.003)$ \\
\hline $6 / 81000$ & $0.806(0.526)$ & $0.930(0.607)$ & $1.123(0.733)$ & $1.440(0.940)$ & $1.532(1.000)$ & $1.536(1.003)$ & $1.536(1.003)$ \\
\hline $7 / 81000$ & $0.800(0.528)$ & $0.920(0.607)$ & $1.111(0.733)$ & $1.425(0.940)$ & $1.516(1.000)$ & $1.521(1.003)$ & $1.520(1.003)$ \\
\hline $8 / 81000$ & $0.795(0.529)$ & $0.912(0.607)$ & $1.092(0.733)$ & $1.403(0.940)$ & $1.502(1.000)$ & $1.507(1.003)$ & $1.507(1.003)$ \\
\hline $9 / 81000$ & $0.792(0.531)$ & $0.904(0.607)$ & $1.084(0.733)$ & $1.401(0.940)$ & $1.491(1.000)$ & $1.495(1.003)$ & $1.495(1.003)$ \\
\hline
\end{tabular}

\section{4. 板状接合試験片の特異応力の強さの解 [基準解]}

第 3 章より，有限要素法を用いて界面における応力分布の比が精度よく求められることがわかった . しかし特

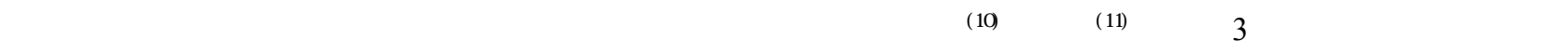
片の特異応力の強さについて, 体積力法を用いて精度よく解析した. 表 3 と図 7 は, $t / W \geq 1$ の場合と同じ板状

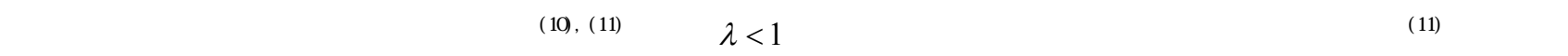
究では全ての材料組合せについて新たに解析し, 表 3 と図 7 に示す. 従って, 図 7 には特異指数 $\lambda>1$ の特異応力 がない $F_{\sigma}>1$ となる範囲もあわせて示した . 新たに解析した範囲は, 特異性がないため有限要素法により容易に 解析できる.しかしながら, 図 7 の破線の範囲の材料組合せに対して, 現在使用している有限要素法コードて計算 を実行することができない．このため，破線の範囲は計算可能な範囲から外光うして求めた . 表 3 と図 7 の基準解 を用いれば接着層厚さが異なる接合板の問題の特異応力の強さは $F_{\sigma} / F_{\sigma \mid t / W=1}$ の比より求められる . 

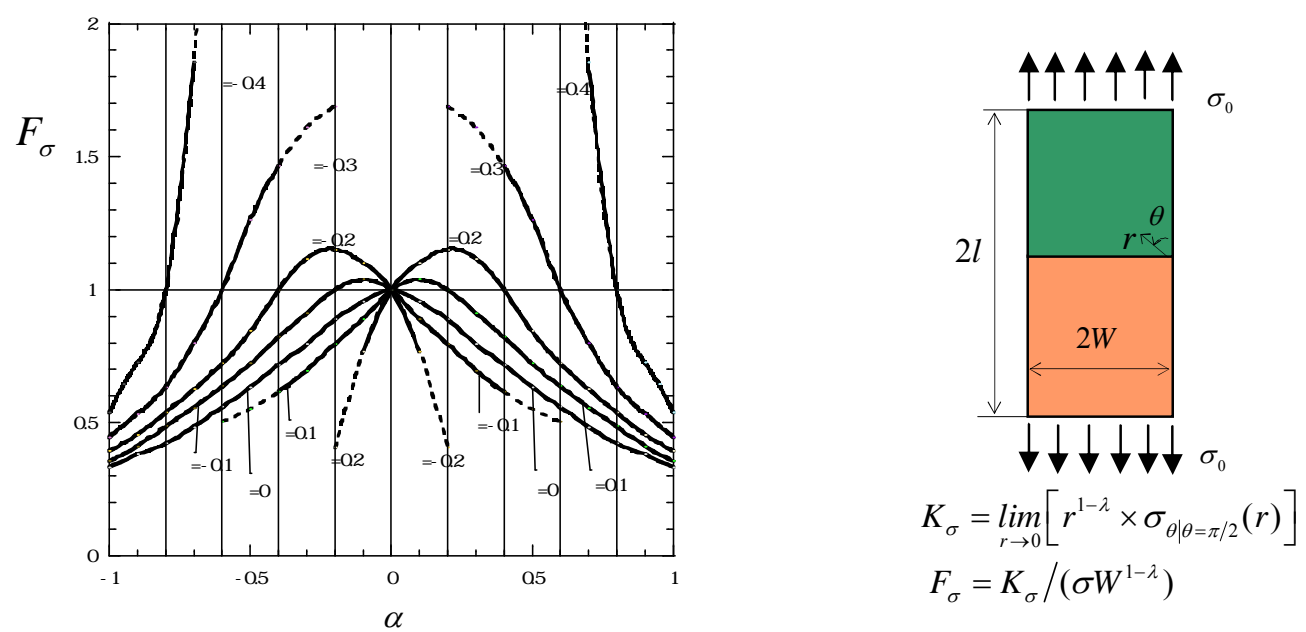

Fig.7 $F_{\sigma}$ for a boned strip in Fig.3 (Note that $F_{\sigma}=1$ when $\alpha(\alpha-2 \beta)=0$ )

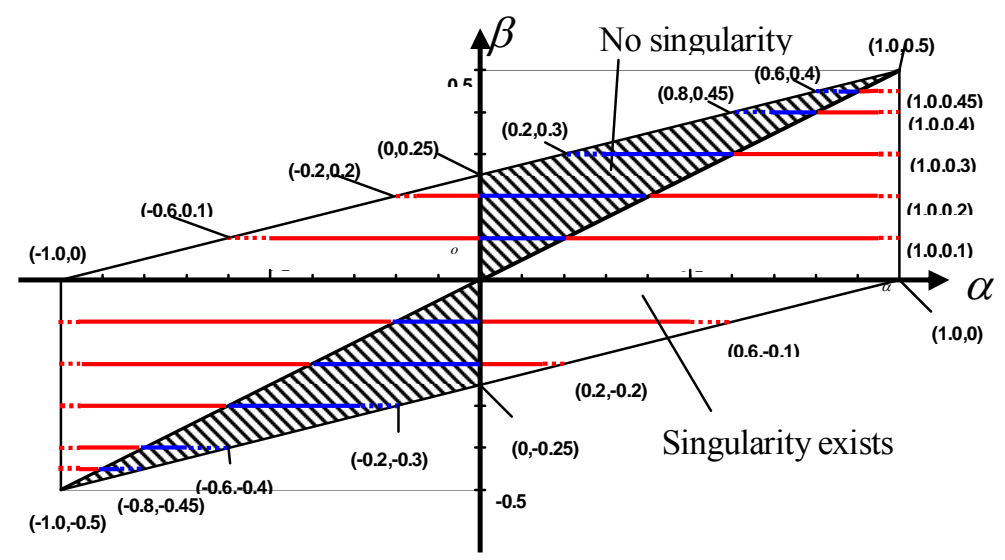

Fig.8 The map of $\alpha$ and $\beta$

Table $3 \quad F_{\sigma}$ at interface edge point in bonded finite plate

[ ( ): Extrapolated or interpolated results. Red figures indicate $\lambda<1$, blue figures indicate $\lambda>1$, black figures indicate $\lambda=1]$

\begin{tabular}{|c|c|c|c|c|c|c|c|c|c|}
\hline$a$ & $\beta=-0.4$ & $\beta=-0.3$ & $\beta=-0.2$ & $\beta=-0.1$ & $\beta=0$ & $\beta=0.1$ & $\beta=0.2$ & $\beta=0.3$ & $\beta=0.4$ \\
\hline-1.00 & 0.540 & 0.446 & 0.395 & 0.357 & 0.332 & -- & -- & -- & -- \\
\hline-0.95 & 0.643 & $(0.349)$ & $(0.381)$ & $(0.422)$ & $(0.491)$ & -- & -- & -- & -- \\
\hline-0.90 & 0.726 & 0.534 & 0.456 & 0.412 & 0.381 & - & - & - & - \\
\hline-0.80 & 1.000 & 0.636 & 0.538 & 0.487 & 0.45 & - & - & - & - \\
\hline-0.70 & $(1.855)$ & 0.800 & 0.626 & 0.558 & 0.486 & - & - & - & - \\
\hline-0.60 & $(3.291)$ & 1.000 & 0.724 & 0.638 & 0.559 & $(0.505)$ & -- & -- & -- \\
\hline-0.50 & - & 1.264 & 0.842 & 0.722 & 0.635 & $(0.551)$ & - & - & -- \\
\hline-0.40 & - & 1.467 & 1.000 & 0.822 & 0.718 & 0.615 & - & - & - \\
\hline-0.30 & -- & $(1.609)$ & 1.118 & 0.913 & 0.796 & 0.697 & - & - & -- \\
\hline-0.20 & -- & $(1.690)$ & 1.153 & 1.000 & 0.889 & 0.797 & $(0.404)$ & -- & -- \\
\hline-0.10 & -- & - & 1.103 & 1.037 & 0.955 & 0.890 & 0.767 & -- & -- \\
\hline 0.00 & -- & - & 1.000 & 1.000 & 1.000 & 1.000 & 1.000 & - & - \\
\hline 0.10 & - & - & 0.767 & 0.890 & 0.955 & 1.037 & 1.103 & - & - \\
\hline 0.20 & - & - & $(0.404)$ & 0.797 & 0.889 & 1.000 & 1.153 & $(1.690)$ & - \\
\hline 0.30 & - & -- & - & 0.697 & 0.796 & 0.913 & 1.118 & (1.609) & -- \\
\hline 0.40 & $\ldots$ & - & - & 0.615 & 0.718 & 0.822 & 1.000 & 1.467 & $\ldots$ \\
\hline 0.50 & - & - & -- & $(0.551)$ & 0.635 & 0.722 & 0.842 & 1.264 & - \\
\hline 0.60 & -- & - & -- & $(0.505)$ & 0.559 & 0.638 & 0.724 & 1.000 & $(3.291)$ \\
\hline 0.70 & -- & -- & -- & - & 0.486 & 0.558 & 0.626 & 0.800 & 1.855 \\
\hline 0.80 & - & - & -- & - & 0.450 & 0.487 & 0.538 & 0.636 & 1.000 \\
\hline 0.90 & - & - & -- & - & 0.381 & 0.412 & 0.456 & 0.534 & 0.726 \\
\hline 0.95 & - & - & -- & - & $(0.491)$ & $(0.422)$ & $(0.381)$ & $(0.349)$ & 0.643 \\
\hline 1.00 & $\ldots$ & $\ldots$ & - & $\ldots$ & 0.332 & 0.357 & 0.395 & 0.446 & 0.540 \\
\hline
\end{tabular}




\section{5. 解析結果および考察}

\section{$5 \cdot 1$ 材料組合せが一般化応力拡大係数に与える影響}

式 (6) に示すように, $F_{\sigma}{ }^{1} / F_{\sigma}{ }^{2}$ の比と $\sigma_{y}{ }^{1} / \sigma_{y}{ }^{2}$ の比は等しいことが示された . 界面に沿って $\sigma_{y}{ }^{1} / \sigma_{y}{ }^{2}$ は一定 であるので, 界面端部付近の $\sigma_{y} / \sigma_{y \mid t / W=1}$ の比を計算することによって全ての材料組合せの $F_{\sigma} / F_{\sigma \mid t / W=1}$ の比を求め ることができる. 図 8 に本解析て使用した材料組合せの $\alpha \beta$ 線図を示す.

図 9 に (a) $t / W=0.001$ と (b) $t / W=0.1$ の場合の $F_{\sigma} / F_{\sigma \mid t / W=1}$ の值を, $\alpha$ と $\beta$ を変化させて示す. また , 表 4 に数值を示す . 図より $\alpha$ が小さいとき， $\alpha$ か増加すると $F_{\sigma} / F_{\sigma t / W=1}$ の比は増加する.一方， $\alpha$ が大きいときは $\alpha$ が増加すると $F_{\sigma} / F_{\sigma \mid t / W=1}$ の比は減少する . (a) $t / W=0.001$ と (b) $t / W=0.1$ の結果を比較すると, $F_{\sigma} / F_{\sigma \mid t / W=1}$ の存在範囲が異なることがわかる . すなわち, $t / W=0.001$ のときの $F_{\sigma} / F_{\sigma \mid t / W=1}$ の值は $0.025 \sim 2.857$ と, 広い範 囲に分布し,$t / W=0.1$ のときは $0.185 \sim 1.498$ と，狭い範囲に分布していることがわかる.

表 4 の $F_{\sigma} / F_{\sigma \mid t / W=1}$ の比と表 3 の $F_{\sigma \mid t / W=1}$ の結果を利用して 図 10 に示すように $t / W=0.001$ と $t / W=0.1$ の $F_{\sigma}$ の 值力得られる。
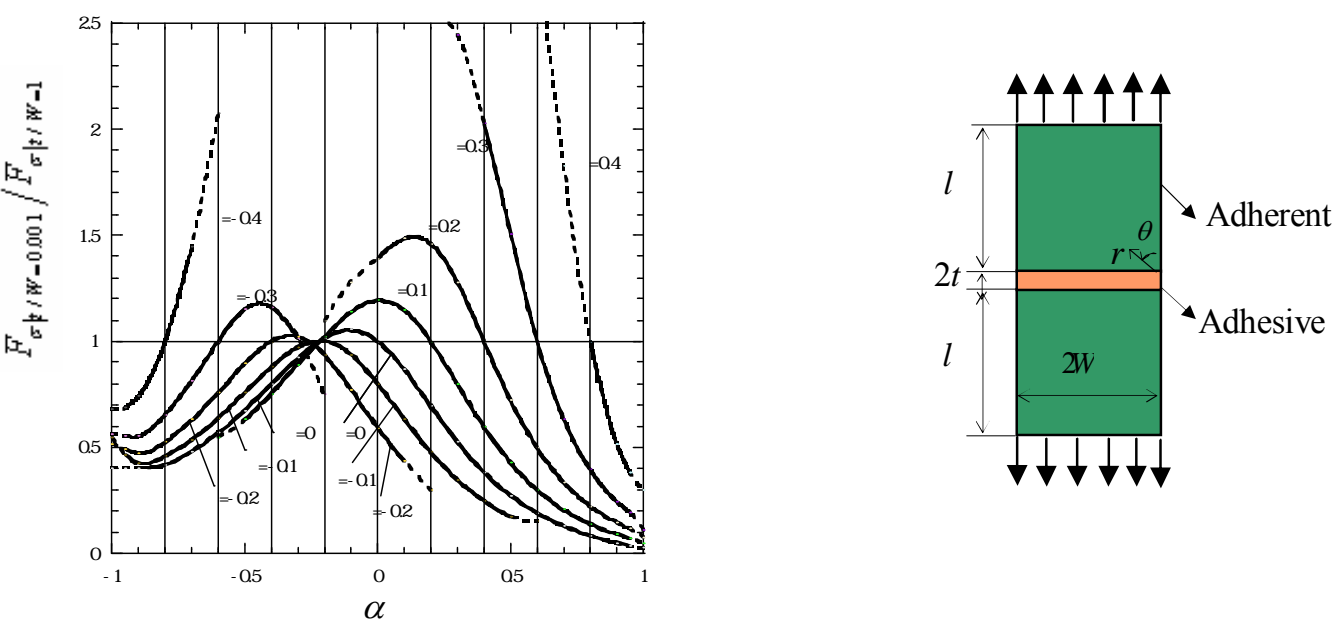

(a)

(b)
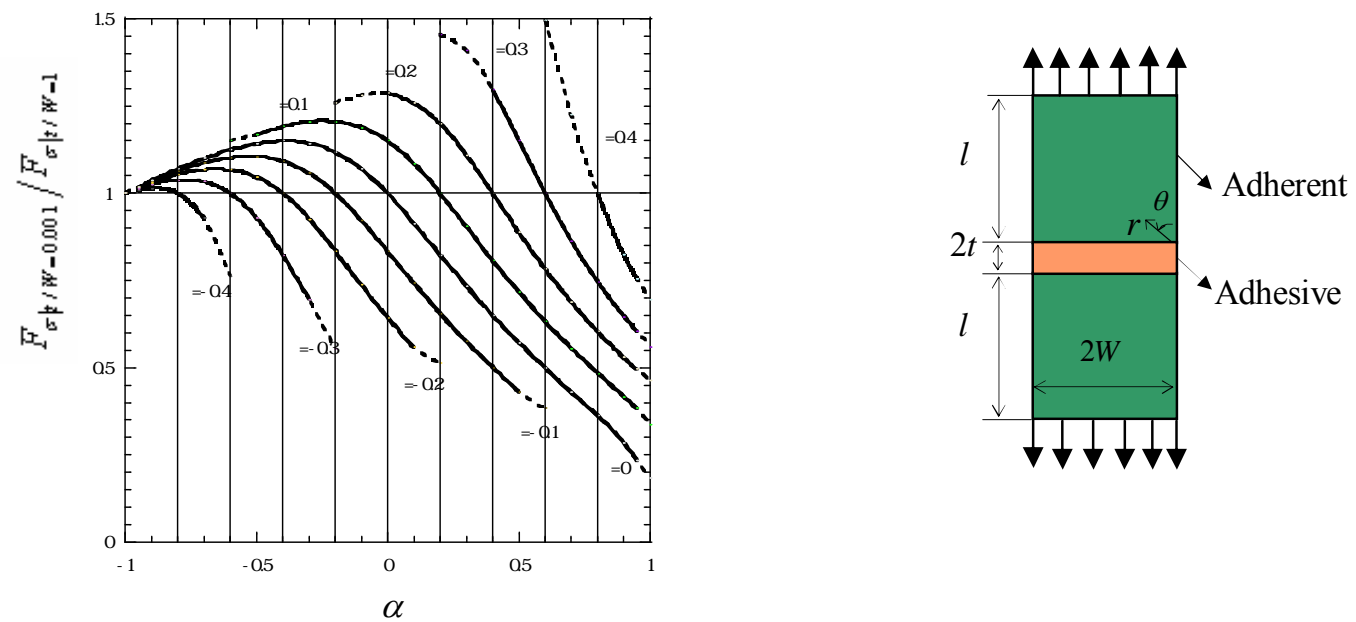

Fig.9 $\quad F_{\sigma} / F_{\sigma t / W=1}$ with varying $\alpha$ and $\beta$ when (a) $t / W=0.001$; (b) $t / W=0.1$ 
Table $4 \quad F_{\sigma} / F_{\sigma \mid t / W=1}$ with varying $\alpha$ and $\beta$ when (a) $t / W=0.001 ;$ (b) $t / W=0.1$

(a) $t / W=0.001$ (Note that $F_{\sigma} / F_{\sigma \mid t / W=1}=1$ when $\alpha=2 \beta$ )

[ ( ): Extrapolated or interpolated results. Red figures indicate $\lambda<1$, blue figures indicate $\lambda>1$, black figures indicate $\lambda=1]$

\begin{tabular}{|c|c|c|c|c|c|c|c|c|c|}
\hline a & $\beta=-0.4$ & $\beta=-0.3$ & $\beta=-0.2$ & $\beta=-0.1$ & $\beta=0$ & $\beta=0.1$ & $\beta=0.2$ & $\beta=0.3$ & $\beta=0.4$ \\
\hline-1.0 & $(0.682)$ & $(0.566)$ & $(0.517)$ & $(0.552)$ & $(0.400)$ & - & - & - & - \\
\hline-0.95 & 0.6864 & 0.5554 & 0.4957 & 0.4629 & $(0.400)$ & -- & -- & -- & -- \\
\hline-0.9 & 0.7420 & 0.5533 & 0.4722 & 0.4252 & 0.4004 & -- & -- & -- & -- \\
\hline-0.8 & 1.0000 & 0.6535 & 0.5254 & 0.4587 & 0.4190 & -- & -- & -- & -- \\
\hline-0.7 & 1.4465 & 0.8130 & 0.6289 & 0.5356 & 0.4812 & -- & -- & -- & -- \\
\hline-0.6 & $(2.073)$ & 1.0000 & 0.7579 & 0.6390 & 0.5690 & $(0.550)$ & -- & -- & -- \\
\hline-0.5 & -- & 1.1509 & 0.8952 & 0.7587 & 0.6769 & 0.6297 & -- & -- & -- \\
\hline-0.4 & -- & 1.1613 & 1.0000 & 0.8794 & 0.7988 & 0.7530 & -- & -- & -- \\
\hline-0.3 & -- & 1.0165 & 1.0232 & 0.9725 & 0.9205 & 0.8924 & -- & -- & -- \\
\hline-0.2 & -- & $(0.750)$ & 0.9346 & 1.0000 & 1.0169 & 1.0203 & $(1.100)$ & -- & -- \\
\hline-0.1 & - & -- & 0.7716 & 0.9372 & 1.0526 & 1.1374 & $(1.280)$ & -- & -- \\
\hline 0 & -- & -- & 0.5912 & 0.7994 & 1.0000 & 1.1925 & 1.3925 & -- & -- \\
\hline 0.1 & -- & -- & 0.4363 & 0.6331 & 0.8665 & 1.1473 & 1.4837 & -- & -- \\
\hline 0.2 & -- & -- & $(0.300)$ & 0.4768 & 0.6938 & 1.0000 & 1.4608 & $(2.524)$ & -- \\
\hline 0.3 & -- & -- & -- & 0.3477 & 0.5253 & 0.7974 & 1.2786 & $(2.443)$ & -- \\
\hline 0.4 & -- & -- & -- & 0.2478 & 0.3834 & 0.5962 & 1.0000 & 2.0311 & -- \\
\hline 0.5 & -- & -- & -- & 0.1728 & 0.2729 & 0.4281 & 0.7223 & 1.5100 & -- \\
\hline 0.6 & -- & -- & -- & $(0.150)$ & 0.1904 & 0.2996 & 0.4984 & 1.0000 & $(2.857)$ \\
\hline 0.7 & -- & -- & -- & -- & 0.1297 & 0.2058 & 0.3355 & 0.6323 & $(1.825)$ \\
\hline 0.8 & -- & -- & -- & -- & 0.0852 & 0.1388 & 0.2224 & 0.3942 & 1.0000 \\
\hline 0.9 & -- & -- & -- & -- & 0.0511 & 0.0913 & 0.1456 & 0.2448 & 0.5173 \\
\hline 0.95 & -- & -- & -- & -- & 0.0348 & 0.0725 & 0.1172 & 0.1930 & 0.3806 \\
\hline 1.0 & - & - & - & - & $(0.025)$ & $(0.050)$ & $(0.080)$ & $(0.110)$ & $(0.300)$ \\
\hline
\end{tabular}

(b) $t / W=0.1$ (Note that $F_{\sigma} / F_{\sigma \mid t / W=1}=1$ when $\alpha=2 \beta$ )

[ ( ): Extrapolated or interpolated results. Red figures indicate $\lambda<1$, blue figures indicate $\lambda>1$, black figures indicate $\lambda=1]$

\begin{tabular}{|c|c|c|c|c|c|c|c|c|c|}
\hline \hline$\alpha$ & $\beta=-0.4$ & $\beta=-0.3$ & $\beta=-0.2$ & $\beta=-0.1$ & $\beta=0$ & $\beta=0.1$ & $\beta=0.2$ & $\beta=0.3$ & $\beta=0.4$ \\
\hline-1.0 & $(1.000)$ & $(1.000)$ & $(1.000)$ & $(1.000)$ & $(1.000)$ & -- & -- & -- & -- \\
\hline-0.95 & 1.0099 & 1.0143 & 1.0164 & 1.0177 & $(1.018)$ & -- & -- & -- & -- \\
\hline-0.9 & 1.0144 & 1.0260 & 1.0312 & 1.0342 & 1.0365 & -- & -- & -- & -- \\
\hline-0.8 & 1.0000 & 1.0390 & 1.0548 & 1.0637 & 1.0698 & -- & -- & -- & -- \\
\hline-0.7 & 0.9275 & 1.0333 & 1.0681 & 1.0870 & 1.0993 & -- & -- & -- & -- \\
\hline-0.6 & $0.764)$ & 1.0000 & 1.0671 & 1.1018 & 1.1239 & $(1.150)$ & -- & -- & -- \\
\hline-0.5 & -- & 0.9298 & 1.0462 & 1.1048 & 1.1415 & 1.1686 & -- & -- & -- \\
\hline-0.4 & -- & 0.8228 & 1.0000 & 1.0916 & 1.1491 & 1.1910 & -- & -- & -- \\
\hline-0.3 & -- & 0.6943 & 0.9269 & 1.0575 & 1.1426 & 1.2051 & -- & -- & -- \\
\hline-0.2 & -- & $0.552)$ & 0.8345 & 1.0000 & 1.1175 & 1.2051 & $(1.260)$ & -- & -- \\
\hline-0.1 & -- & -- & 0.7361 & 0.9219 & 1.0698 & 1.1890 & $(1.280)$ & -- & -- \\
\hline 0 & -- & -- & 0.6433 & 0.8324 & 1.0000 & 1.1501 & 1.2864 & -- & -- \\
\hline 0.1 & -- & -- & 0.5579 & 0.7413 & 0.9144 & 1.0856 & 1.2580 & -- & -- \\
\hline 0.2 & -- & -- & $(0.513)$ & 0.6548 & 0.8229 & 1.0000 & 1.1994 & $(1.453)$ & -- \\
\hline 0.3 & -- & -- & -- & 0.5748 & 0.7332 & 0.9037 & 1.1092 & $(1.409)$ & -- \\
\hline 0.4 & -- & -- & -- & 0.5007 & 0.6492 & 0.8071 & 1.0000 & 1.2962 & -- \\
\hline 0.5 & -- & -- & -- & 0.4307 & 0.5715 & 0.7160 & 0.8879 & 1.1518 & -- \\
\hline 0.6 & -- & -- & -- & $0.382)$ & 0.4994 & 0.6324 & 0.7828 & 1.0000 & $(1.498)$ \\
\hline 0.7 & -- & -- & -- & -- & 0.4309 & 0.5561 & 0.6882 & 0.8635 & $(1.224)$ \\
\hline 0.8 & -- & -- & -- & -- & 0.3625 & 0.4855 & 0.6040 & 0.7467 & 1.0000 \\
\hline 0.9 & -- & -- & -- & -- & 0.2851 & 0.4180 & 0.5291 & 0.6479 & 0.8241 \\
\hline 0.95 & -- & -- & -- & -- & 0.2329 & 0.3836 & 0.4947 & 0.6046 & 0.7544 \\
\hline 1.0 & -- & -- & -- & -- & $0.185)$ & $0.339)$ & $0.463)$ & $0.560)$ & $(0.697)$ \\
\hline
\end{tabular}



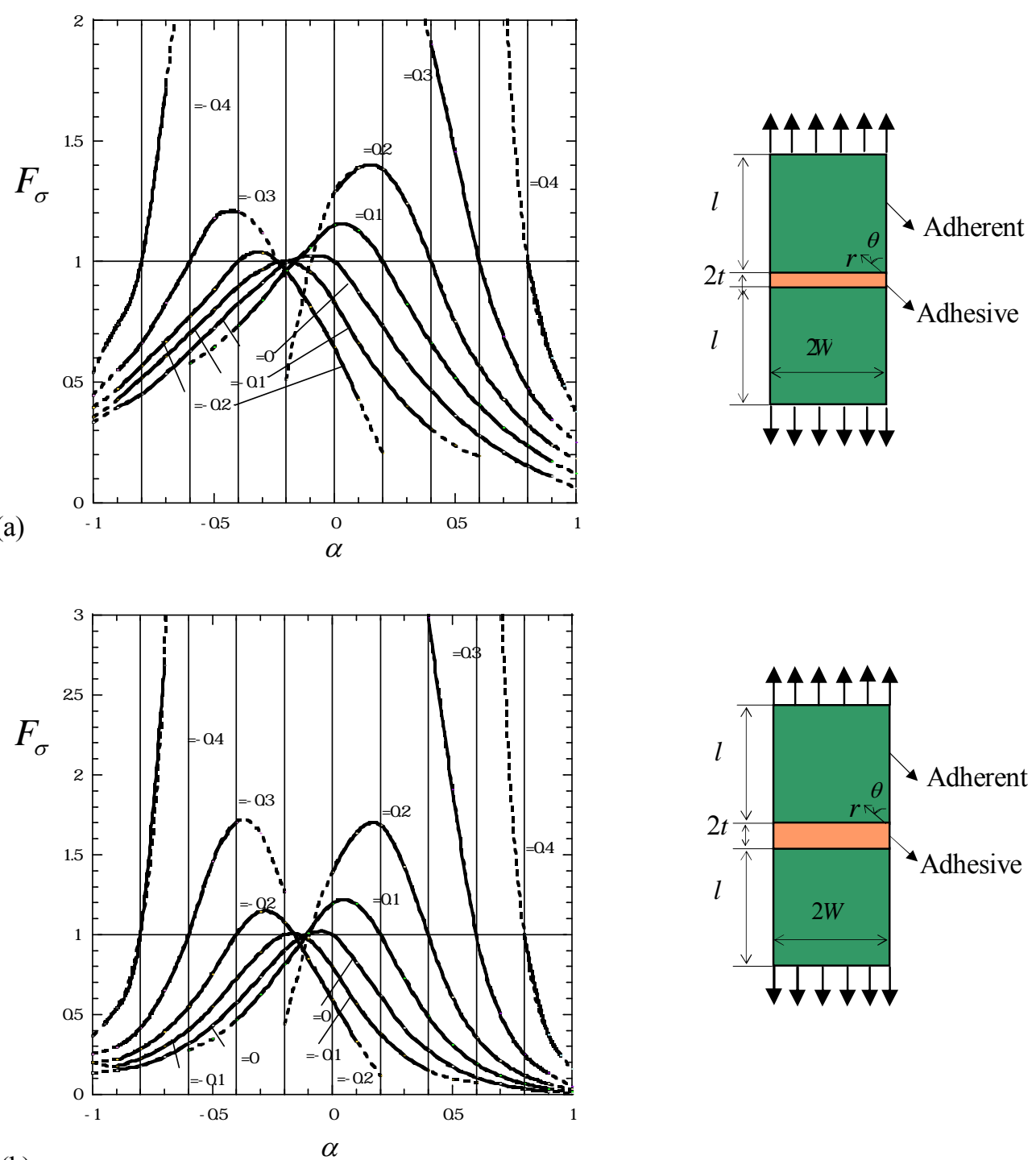

(b)

Fig.10 $\quad F_{\sigma}$ with varying material combination $\beta$ when (a) $t / W=0.001$; (b) $t / W=0.1$

\section{$5 \cdot 2$ 接着層厚さか特異応力場の強さに与える影響}

接着層厚さか特異応力の強さに与える影響を調べるために，まず被接着剤としてステンレス SUS304 とアルミ ニウム合金 A7075 とシリコンと IC 基板の FR-4.5 (12) を考える . また , 接着斉は樹脂とする . 表 5 に接着㶡と被 接着斉の物性值を示す. 表 6 に $t / W=0.001,0.01,0.1,0.5,2,4$ における界面の $K_{\sigma} / K_{\sigma \mid t / W=1}$ の比を示す. 表 6 をグ ラフにしたのか泪 11 である $. t / W<1$ の範囲では $t / W$ か増加すると $F_{\sigma} / F_{\sigma \mid t / W=1}$ の值も増加し,$t / W>1$ の範囲 ではどの材料組合せでも $F_{\sigma} / F_{\sigma|t| W=1}$ の值は 1.0 となる .

一般的に接着斉のヤンク率 $E_{2}$ は被接着斉のヤンク率 $E_{1}$ より小さく $\left(E_{2} \leq E_{1}\right)$, 接着斉のポアソン比 $v_{2}$ は, 被 接着斉のポアソン比 $v_{1}$ より大きい $\left(v_{2} \geq v_{1}\right)$.この場合は $\alpha \geq 0$ かつ $\alpha-2 \beta \geq 0$ であるので, 界面端部付近におい て特異応力か発生する. 表 4 の值から樣々な $t / W$ に対して $F_{\sigma} / F_{\sigma \mid t / W=1}$ を両対数グラフに整理し， $\beta=-0.2$ から $\beta=0.4$ まで $\beta$ を一定として $\alpha$ を変化させて図 12 に示す.図 12 より $\alpha \geq 0$ かつ $\alpha-2 \beta \geq 0$ のときは,全ての組合

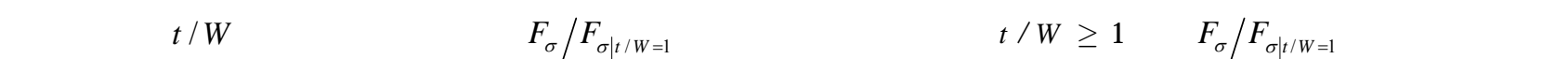
なる . 界面強度を改善させるためには, 接着層厚さは薄いほうか望ましい. すなわち, 接着層厚さか薄いと特異 応力場の強さが咸少することか特異応力場の強さの観点から明らかとなった．

また 図 12 より $\alpha-2 \beta=0$ のとき $t / W$ によらず $F_{\sigma} / F_{\sigma \mid t / W=1}=1$ であることがわかる 一方,$\alpha \geq 0$ かつ $\alpha-2 \beta>0$ のときには, $t / W$ が減少すると $F_{\sigma} / F_{\sigma \mid t / W=1}$ は常に減少することがわかる. 
Table 5 Material properties

\begin{tabular}{|l|l|l|l|}
\hline \hline & Material & Elastic Modulus/Gpa & Poissons ratio \\
\hline \multirow{4}{*}{ Adherent } & SUS304 (stainless steel ) & 206 & 0.3 \\
\cline { 2 - 4 } & A7075 (aluminum alloys ) & 71 & 0.33 \\
\cline { 2 - 4 } & Silicon & 166 & 0.26 \\
\cline { 2 - 4 } & FR-4.5 (IC substrate) & 15.34 & 0.15 \\
\hline Adhesive & Resin & 2.74 & 0.38 \\
\hline
\end{tabular}

Table $6 \quad F_{\sigma} / F_{\sigma \mid t / W=1}$ with varying adhesive thickness $t / W$

\begin{tabular}{|c|c|c|c|c|}
\hline$t / W$ & SUS304 & A7075 & Silicon & FR-4.5 \\
\hline 0.001 & 0.100 & 0.118 & 0.102 & 0.229 \\
\hline 0.01 & 0.212 & 0.236 & 0.215 & 0.355 \\
\hline 0.1 & 0.466 & 0.4884 & 0.468 & 0.573 \\
\hline 0.5 & 0.898 & 0.903 & 0.898 & 0.916 \\
\hline 1 & 1.000 & 1.000 & 1.000 & 1.000 \\
\hline 2 & 1.002 & 1.002 & 1.002 & 1.003 \\
\hline 4 & 1.002 & 1.002 & 1.002 & 1.003 \\
\hline
\end{tabular}

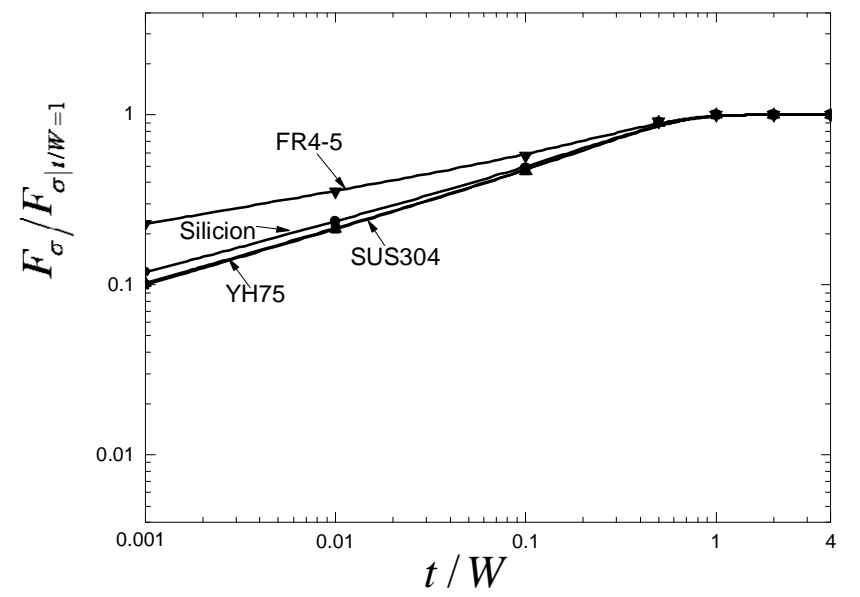

Fig.11 $F_{\sigma} / F_{\sigma \mid t / W=1}$ with varying adhesive thickness $t / W$

6. 結言

本研究では接着材で接合された接合板の接着層端部での特異応力の強さについて, 接着層厚さと材料組合せを 変化させて議論した . 本論文の結論をまとめると以下のようになる .

(1) 接着接合板の特異応力場の強さを有限要素法を用いて精度よく計算する方法を提案した .接着層厚さの異な る 2 つの接合板の問題を問題 1 , 問題 2 とするとき, 特異応力場の強さの比 $K_{\sigma}^{1} / K_{\sigma}^{2}$ は, 接合界面上の応力の比 $\lim _{r \rightarrow 0}\left(\sigma_{\theta \mid \theta=\pi / 2}^{1} / \sigma_{\theta \mid \theta=\pi / 2}^{2}\right)$ より求められることを示した . また, 適当なメッシュを用いて有限要素法解析を行えば， $K_{\sigma} / K_{\sigma \mid t / W=1}$ の比が , メッシュサイズに依存しないことが明らかとなった . しかも , 界面においては応力の比は一 定である.したがって,$K_{\sigma} / K_{\sigma|t| W=1}$ の比を計算するとき最初の節点の応力値のみ考慮すればよいことを明らかに した。

（2）材料組合せの特異応力場の強さ $K_{\sigma}$ への影響を考察した . 図 7 およひ図 10 に示すように Dunders パラメー ターの $\beta$ の值を固定すると， $\alpha$ が小さいときには $\alpha$ が増加すると $K_{\sigma}$ も増加することがわかった . 一方 , $\alpha$ が大 

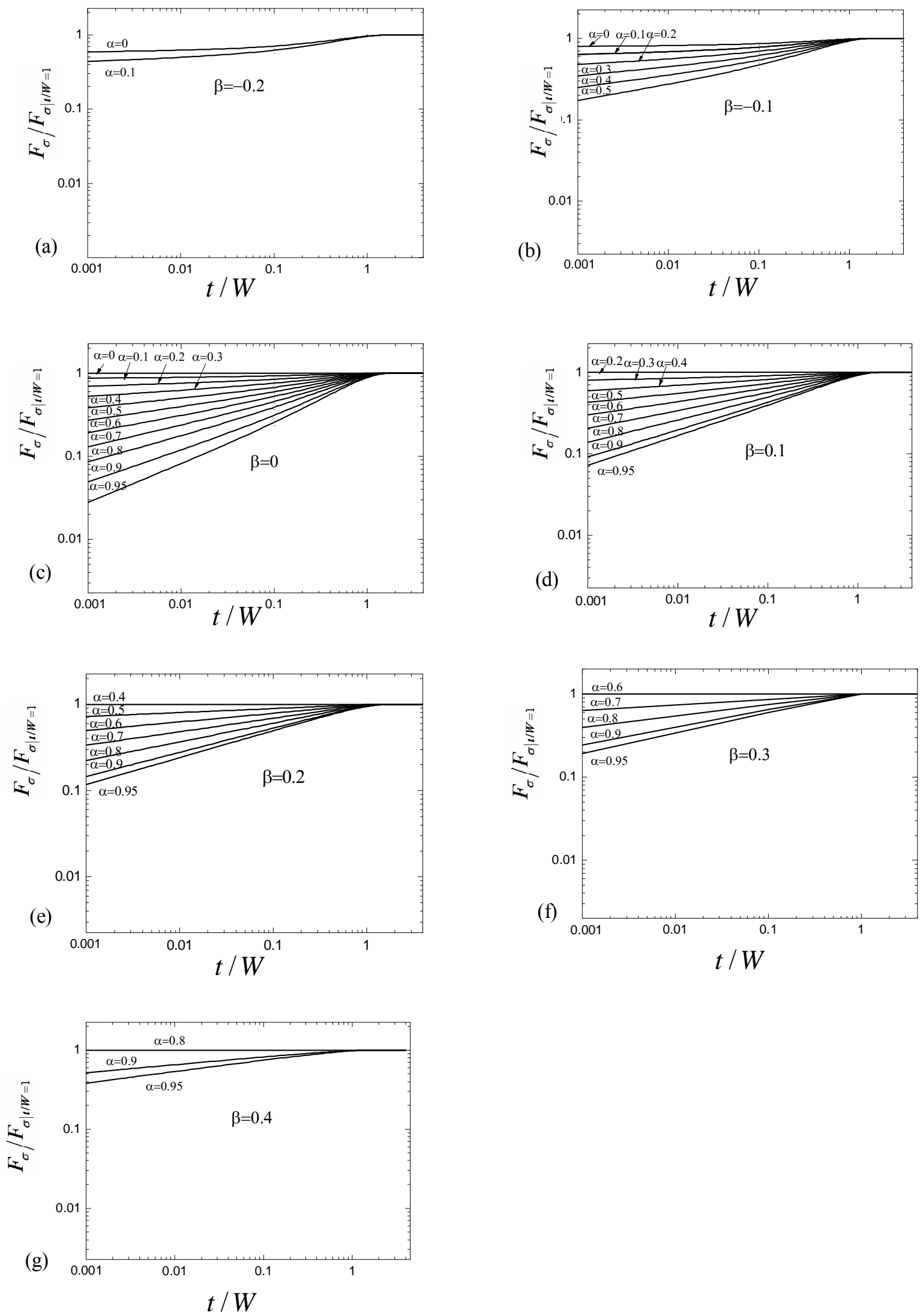

Fig.12 $F_{\sigma} / F_{\sigma / t / W=1}$ with $t / W$. (a) $\beta=-0.2$; (b) $\beta=-0.1$; (c) $\beta=0$; (d) $\beta=0.1$; (e) $\beta=0.2$; (f) $\beta=0.3$; (g) $\beta=0.4$ 
きいときは $\alpha$ か増加すると $K_{\sigma}$ は減少することがわかった . 特異応力場の強さ $K_{\sigma}$ の存在範囲は接着層厚さ である $t / W$ に応じて変化することを示した .

(3) 界面強度を強化するためには薄い接着層のほうか望ましい.なぜなら特異応力場の強さ $K_{\sigma}$ は接着層か薄 くなると減少するためである . また $K_{\sigma}$ の変化の程度は材料組合せによって異なる . どの材料組合せにおいても $t / W \geq 1$ の場合には , 比 $K_{\sigma} / K_{\sigma \mid t / W=1}=1$ となる .

\section{文献}

(1) Kanno, T., Ogata, M., and Foxton, R.M., etc, "Microtensile Bond Strength of Dual-cure Resin Cement to Root Canal Dentin with Different Curing Strategies", Dental Material, Vol. 23, No. 4 (2004), pp. 550-556.

(2) Kitasako, Y., Burrow, M.F., and Nikaido, T., etc, "Shear and Tensile Bond Testing for Resin Cemented with SixLluting Agents", The Journal of Prosthetic Density, Vol. 80 (1995), pp.423-428.

(3) Van Meerbeek, B., De Munck, J., and Yoshida, Y., etc, "Buonocore Memorial Lecture-Adhesion to Enamal and Dentin: Current Status and Future Challenges", Operative Dentistry, Vol. 28 (2003), 215-235.

(4) Park, J.H., Choi, J.H., and Kweon, J.H., "Evaluating the Strenghts of Thick Aluminum-to-Aluminum Joint with Different Adhesive Lengths and Thicknesses", Composite Structures (2009), pp. 1-10.

(5) Arenas, J., Narbon, J.J., and Alia, C., "Optimum Adhesive Thickness in Strutural Adhesive Joints Using Statistical Techniques based on Weibull Distribution", Internaltional Journal of Ahesion\&Adhesives (2009), pp. 1-6.

(6) Neves, A.A., Courinho, E., and Poitevin, A., "Influence of Joint Component Mechanical Properties and Adhesive Layer Thickness on Stress Distribution in Micro-tensile Bond Strength Specimens", Dental Materials, Vol.25 (2009), pp. 4-12.

(7) Afendi, M., and Teramoto.T., "Fracture Toughness Test of Epoxy Adhesive Dissimilar Joint with Various Adhesive Thickness", Proceedings of Asian Pacific Conference for Materials and Mechanics (2009), a55.

(8) Bogy, D.B., "Edge-Bonded Dissimilar Orthogonal Elastic Wedges under Normal and Shear Loading" , Journal of Applied Mechanics, Vol. 35, (1968), pp. 460-466.

(9) Bogy, D.B., "Two Edge-Bonded Elastic Wedges of Different and Wedge Angles under Surface Tractions", Journal of Applied Mechanics, Vol. 38, (1971), pp. 377-386.

(10) 陳玳行，西谷弘信，“板状接合試験片における特異応力場の強さ”，日本機械学会論文集 A 編，Vol .59, No . 567 (1993), pp . 2682-2686.

(11) 野田尚昭, 白尾亮司, 李俊, 杉本淳典, “強化繊維の引抜きにおける䋊維端部の特異応力場の強さ”，日本機 械学会論文集 A 編，Vol . 72, No . 721 (2006)，pp . 1397-1404.

(12) Nakajima, M., Koguchi, H., "Influence of Interlayer Thickness on the Intensity of Singular Stress Field in 3D Three-layered Joints Under an External Load", Proceedings of Asian Pacific Conference for Materials and Mechanics, (2009),a112. 